\title{
Island ecosystem services value, land-use change, and the National New Area Policy in Zhoushan Archipelago, China
}

\author{
Shuangshuang Qiu \\ Department of Land Management, Zhejiang University, China \\ ssqiu@zju.edu.cn \\ Wenze Yue \\ Department of Land Management, Zhejiang University, China \\ wzyue@zju.edu.cn (corresponding author) \\ Huan Zhang \\ College of Civil Engineering and Architecture, Zhejiang University, China \\ 0014979@zju.edu.cn (corresponding author)
}

and

Jiaguo Qi

Ocean College, Zhejiang University, China

Center for Global Change \& Earth Observations, Michigan State University, USA

qi@msu.edu

\begin{abstract}
Inhabited islands in China now face increasing stress from urbanisation and related development policies. Since the National New Area was established in 2011, dramatic land-use changes in the Zhoushan Archipelago have affected its ecosystem health and biodiversity. The National New Area policy further promoted Zhoushan's economic development but exerted more pressure on its ecosystems. To explore sustainable development, this study attempts to determine how ecosystems in the archipelago have been impacted through the variation in ecosystem services value (ESV) by means of the InVEST model. The outcomes indicate that: (i) the total ESV and carbon storage have declined, with a remarkable increase in built-up land and decrease in farmland and wetland; (ii) the encroachment on farmland and wetland by built-up land is identified as the main reason for the impairment of ecosystem services; (iii) the National New Area policy has affected the island ecosystems by transforming the orientation of development to a national strategic position, encouraging specific kinds of spatial planning with different development patterns and focuses, and introducing preferential policies on administration, land use, etc.
\end{abstract}

Keywords: China, ecosystem services value, InVEST model, island cities, Zhoushan Archipelago

https://doi.org/10.24043/isj.20

(C) 2017 - Institute of Island Studies, University of Prince Edward Island, Canada.

\section{Introduction}

Ecosystems provide a range of services of fundamental importance to human well-being, health, livelihoods, and survival (Costanza et al., 1997; Costanza et al., 2014; MEA, 2005; TEEB Foundations, 2010; TEEB Synthesis, 2010). Ecosystem services represent the benefits that living organisms derive from ecosystem functions that maintain the Earth's life-support system, including climate regulation, 
water supply, and nutrient cycling (Costanza et al., 1997). However, over the long-term process of utilising and transforming nature, we typically emphasise only the direct consumer value or market value of natural resources while neglecting ecosystem services and their value (Chen \& Zhang, 2000).

The International Environment Research Group was the first team to be engaged in probing ecosystem service functions for humans (SCEP, 1970). Ehrlich and Ehrlich (1981) proposed the concept of 'ecosystem services' and systematically studied whether biodiversity loss would affect ecosystem service functions. Since 1990, numerous studies have been conducted to explore both the concepts and valuation techniques of ecosystem services. Notable examples include the publication of Nature's Services: Societal Dependence on Natural Ecosystems by Daily (1997) and the research conducted by Costanza et al. (1997), who presented the principles and methods for estimating the global value of 17 ecosystem services provided by 16 dominant global biomes. In 2005, the concept of ecosystem services gained broader attention in both research and policy communities when the United Nations published its Millennium Ecosystem Assessment (Braat \& de Groot, 2012; Costanza et al., 2014; Costanza \& Kubiszewski, 2012). Subsequently, The Economics of Ecosystems and Biodiversity (TEEB) report undertaken by the UN Environment Programme was picked up extensively by the mass media, bringing ecosystem services to a broader audience (Costanza et al., 2014). Hundreds of projects and groups are currently working toward improved understanding, modeling, valuation, and management of ecosystem services and natural capital (Costanza et al., 2014).

Islands are an indispensable element of coastal zones, and island ecosystems differ from terrestrial ecosystems. The Millennium Ecosystem Assessment (MEA) (2003) defines islands as "lands isolated by surrounding water and with a high proportion of coast to hinterland." An island and its surrounding seas comprise an integrated system, and island ecosystems provide both terrestrial and marine ecosystem services (Lin et al., 2013). Islandness likewise strengthens the links between a place's ecosystem services and the inhabitants of the place itself (Aretano et al., 2013; D. Wang et al., 2014). Islands are among the most vulnerable places to human activities and environmental change (Chen et al., 2013), with the result that they have attracted significant attention from researchers in recent years.

Since the 1990s, studies on island ecosystems have focused mainly on assessing ecosystem services and health (Parsons et al., 2008; D. Wang et al., 2014; Xu et al., 2004; Zhao et al., 2004), ecological degradation and restoration (Samways, 2000; Samways et al., 2010; Shi et al., 2012), management and planning of islands and their surrounding seas (Oost et al., 2012; Saunders, 1990; Sovacool, 2012), and the response of island ecosystems to anthropogenic effects (Angeler \& Alvarez-Cobelas, 2005; Lin et al., 2013; Wang et al., 2010). Land-use and land-cover changes are underlying causes of the fragmentation and loss of natural habitat (Alcamo \& Bennett, 2003). Human encroachment into surrounding natural and semi-natural ecosystems has impaired regional ecosystem service functions (Wu et al., 2013), particularly on islands. Substantial research has been conducted into techniques for evaluating ecosystem services. Methods of monetary valuation have drawn the most attention from researchers because they make 'unpriced' services comparable with services that have market value, enable the aggregation of various ecosystem services, and allow full-cost accounting (Wang et al., 2010). A range of methods for monetary valuation have been developed, including the direct market approach, surrogate market approach, experimental market approach, and benefit transfer method (Curtis, 2004; Farber et al., 2002; Freeman et al., 2014; Wang et al., 2010).

Several inhabited islands in China now face increasing stress from urbanisation (Lin et al., 2013). Urban spatial expansion on Xiamen Island over the past 30 years has occupied large areas of woodland, farmland, water area, and coastal wetland, thereby decreasing the ecosystem services value (ESV) and significantly fragmenting the landscape pattern (Lin et al., 2013). Land reclamation projects were conducted there to ease land shortage but led to ecosystem service losses (Wang et al., 2010). Zhao et al. (2004) also discovered that the total ESV of Dongtan in the East Beach of Chongming Island declined from 1990 to 2000, which was largely attributable to the loss of tidal flats. The intensity of human activities is closely dependent on national or regional development strategies and varies across different periods, causing discontinuous changes in land use or ecosystems. However, few attempts 
have been made to research the influence of development policies, especially national development policies, on ecosystem services, regardless of the degree, direction, and mechanism of the effects.

Similar challenges have confronted the Zhoushan Archipelago, which is located in the northeastern seas of China's Zhejiang province. Analyses of land-use and land-cover changes from a long-term series of remote sensing data in Zhoushan Archipelago revealed that built-up areas have expanded sharply at the cost of the tidal zone and arable lands from 1970 to 2011: Most of these areas are located around the periphery of the archipelago's islands (Chen et al., 2013; X. Zhang et al., 2013). Such dramatic land-use changes, mainly driven by urbanisation and development policies, have contributed to an overall decrease in ecosystem health (Lu et al., 2010) and a slight decline in the function of biodiversity (Lin, 2015). The Zhoushan Archipelago New Area was set up in 2011 to enhance China's maritime economy, expand its marine development strategy, and promote its ability to integrate global resources (Long et al., 2014). That is, development and further urbanisation in this area will undoubtedly continue. Thus, to explore sustainable management and guide future island development, it is of great importance to understand the state of the islands' natural environment and ecosystems before and after implementation of the National New Area policy.

This study uses the research method developed by Xie et al. (2008) - with some adaptations to the local situation in the Zhoushan Archipelago - to calculate ESV as well as introduces the integrated valuation of environmental services and tradeoffs (InVEST) model, a widely applied tool for ecosystem service mapping and valuation (Kareiva, 2011). This paper presents systematic research into the dynamic patterns of land use and ESV in Zhoushan, using remote sensing images in 2009 and 2014 as well as socioeconomic and ecological data from the scholarly literature and government sources. We aim to determine changes in land use, ESV, and carbon storage over the study period; reveal how the National New Area policy has influenced ecosystem services in the archipelago; and provide preliminary policy recommendations to explore sustainable use of the islands.

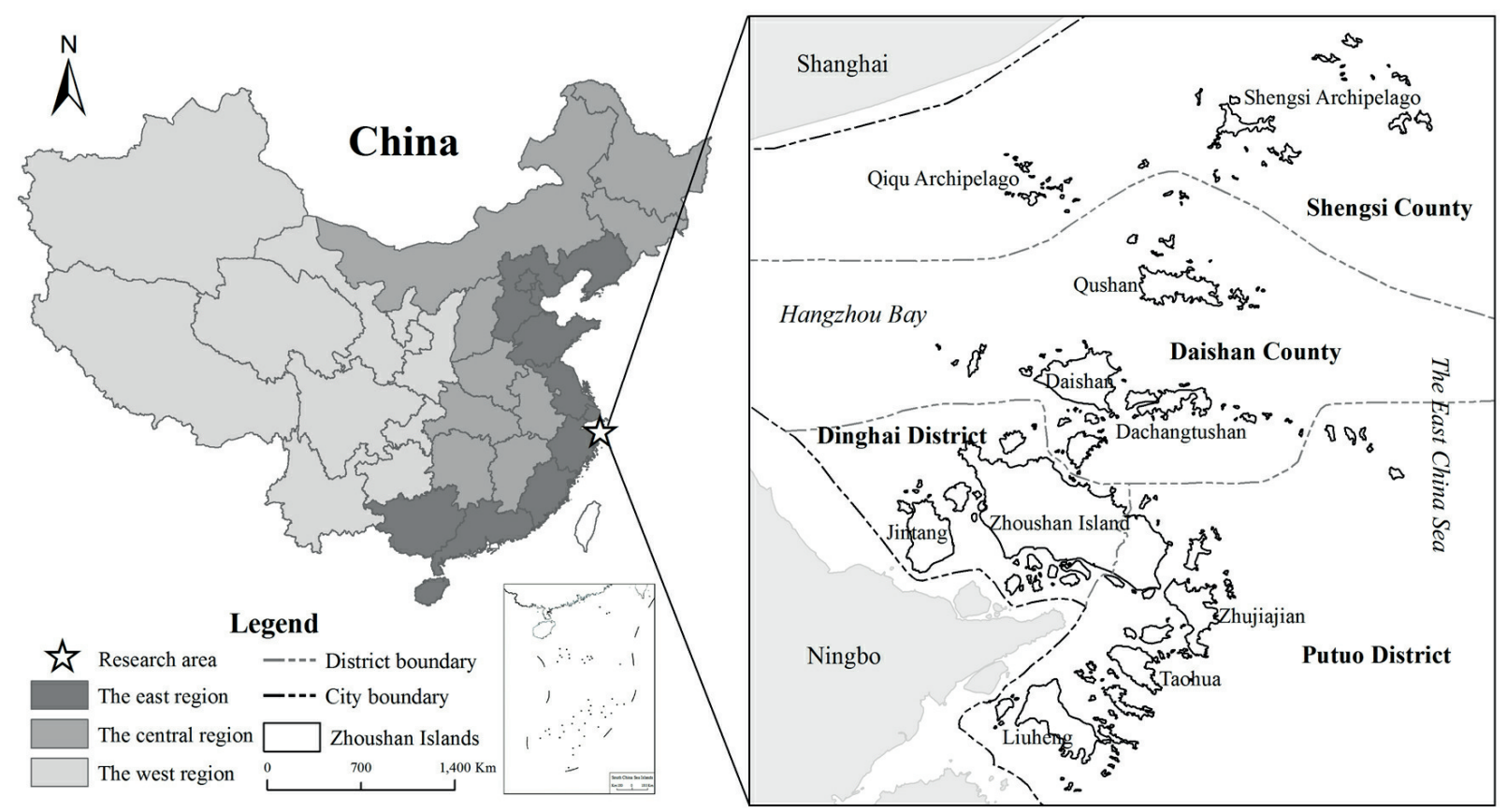

Figure 1: Study area.

\section{Data and methods}

Study area

The Zhoushan Archipelago $\left(29^{\circ} 32^{\prime}-31^{\circ} 04^{\prime} \mathrm{N}, 121^{\circ} 30^{\prime}-123^{\circ} 25^{\prime} \mathrm{E}\right)$ is located on China's eastern coast. The study area is at the intersection of the Yangtze River Estuary and Hangzhou Bay, close to Ningbo. 
This area includes 583 islands and has a land area of $1027.4 \mathrm{~km} 2$, with over $1200 \mathrm{~km}$ of coastline. It comprises two districts of the Zhoushan Archipelago, namely, Dinghai and Putuo (Figure 1). These two districts were identified as the planned urban area by the local development master plan, were more developed, and received more anthropogenic effects than Zhoushan's two other counties, Daishan and Shengsi. The study area is comprised of a hilly landscape, with a monsoon-influenced subtropical marine system climate (X. Zhang et al., 2013). The mean annual temperature is $16.1^{\circ} \mathrm{C}$, and the average annual rainfall is around $1200 \mathrm{~mm}$. Coniferous, evergreen broad-leaved, and deciduous broad-leaved forests are widely distributed (X. Zhang et al., 2013).

The National New Area is set up by the State Council and undertakes national strategic developmental and reform activities, aiming to: allow full utilisation of potential comparative and competitive advantages, optimise industrial layout, and improve economic quality and efficiency in each selected region. The general development target and orientation of the New Areas are uniformly planned and approved by the State Council. Open and preferential policies also favor these areas. In 1992, the first National New Area, the Pudong New Area of Shanghai, was established, and since then 18 further New Areas have been set up (as of April 2017), including the Binhai New Area of Tianjin and the Lanzhou New Area of Gansu.

The Zhoushan Archipelago New Area is the fourth National New Area and the first New Area with a marine economy theme. This New Area prioritises the industrial development of ports, logistics, shipbuilding, manufacturing of marine engineering equipment, marine tourism, and pelagic fishery. It is designed as a base for modern marine industry, an ecological island city, and a maritime garden city. Over the past decade, Zhoushan has undergone unprecedented expansion (Chen et al., 2013). In 2013, the archipelago's permanent population was 1,142,000 people, the population density reached 793 people per km2, the Gross Domestic Product (GDP) per capita amounted to 81,582 yuan, and the added value of the marine economy accounted for $69.10 \%$ of Zhoushan's GDP. With the initiation of the Peninsula Project in 1997 and the construction of cross-sea bridges, Zhoushan's development has been subjected to continually strengthening mainland-island contact, which has exerted great pressure on the archieplago's limited land resources and ecosystems.

\section{Data collection and processing}

This study utilises remote sensing images to interpret land-use changes; utilises equivalent value coefficients (EVC) proposed by Xie et al. (2008) and revisions based on socioeconomic and ecological data from local and national governments to evaluate ESV; and utilises carbon density data from the literature to compute carbon storage and sequestration values. Equivalent value coefficients (EVC) refer to equivalent factors for ecosystem services value.

Land-use and land-cover change data were produced from a Landsat5 TM (Thematic Mapper) image $(30 \mathrm{~m})$ and a GF-1 WFV4 image $(19 \mathrm{~m})$, which were acquired on 17 July 2009 and 16 March 2014 respectively. Geometrical rectification, coordinate system unification, crop processing, and interpretation were performed using the ERDAS IMAGINE software. Due to the research scope and available data, we could only adopt moderate-resolution remote sensing images, which thereby limited our classification scheme. Given that many relevant studies also adopt such a classification scheme, and bearing in mind Zhoushan's land-use status, five land-use categories were defined and classified in this study: forest (woodland and garden plots), farmland (paddy field and dryland), wetland (aquaculture area and coastal wetland), water area (rivers, lakes, and reservoirs), and built-up land (urban area; rural settlements; bare land; land for industry, mining, and transportation; and industrial salt flats). The various subcategories were roughly determined to improve our understanding of the situation, but they were not determined from interpretation of the remote sensing images. Supervised classification, a technique for developing the rules for assigning reflectance measurements to land-use categories based on sufficient known pixels and a predefined algorithm, was applied to guarantee classification consistency and accuracy, combined with human-machine interactive interpretation. The Kappa coefficients validated by Google Maps were 88.57\% in 2009 and 87.62\% in 2014, which met the recommended value suggested by Janssen and Vanderwel (1994). 


\section{Computation of ESV}

When detailed valuation data are unavailable for a study region, the benefit transfer method is recognised as a useful way to bridge the data gap (Wang et al., 2010). Based on the pioneering work of Costanza et al. (1997), Xie et al. (2003) developed an enhanced benefit transfer method to evaluate China's terrestrial ecosystem services by surveying 200 Chinese ecologists in 2002. This method was successfully utilised in an ecological assets valuation of the Tibetan Plateau. Xie et al. (2008) subsequently modified the EVC from their previous study through a survey of 500 Chinese ecologists in 2007. The method of Xie et al. (2008) is relatively feasible and has been widely applied in China (Lin et al., 2013; W. Wang et al., 2014; Wu et al., 2013). To compensate for the deficiency of static evaluation, which can only be utilised to evaluate the ESV of a particular year at a national scale, Xie et al. (2015) further proposed more detailed EVC and an integrated method for dynamic evaluation of Chinese terrestrial ESV at monthly and provincial scales by introducing space-time adjustment factors of NPP (Net Primary Productivity), precipitation, and soil conservation.

Given the accessibility of data, this study adopted the EVC proposed by Xie et al. (2008). Each land-use type provided nine service functions (Table 1). The food production function per unit farmland was set as the standard, with an EVC of 1. EVCs of other ecosystem services were estimated by the surveyed Chinese ecologists, who compared them with the standard value. However, ecosystems are idiosyncratic (Daily et al., 2000). Direct application in a particular area of the EVC that is suitable for the entire country may lead to inaccurate results. Therefore, this study rectified the EVC based on the specific circumstances of the study area.

First, area rectification was conducted (Xu et al., 2012). The EVC benchmark in Xie et al. (2008) was the average food production of farmland per hectare per year in China. By assuming that the proportional relationship among the EVCs of different land-use types remained constant, we adjusted the benchmark to the average food production of farmland per hectare per year in the study area to reflect the ESV spatial disparity between the study area and the country as a whole. The formula of area rectification was as follows:

$$
E_{i j}{ }^{\prime}=\frac{q}{Q} \times E_{i j}
$$

Where $q$ and $Q$ are the average food production of farmland per hectare per year in the study area and in China respectively; $E_{j j}$ and $E_{j j}$ ' are the EVCs of ecosystem service function $j$ of land-use type $\mathrm{i}$ before and after rectification. The factor of area rectification of the study area was 1.16 (Appendix A1) (National Bureau of Statistics of China, 2013; Zhoushan Bureau of Statistics, 2013).

Second, the EVC of forest ecosystem were separately rectified because it composed a large proportion of the study area (Ai \& Hong, 2015; Xu et al., 2012). Forest biomass usually varies in different regions due to different types of plants and hydrothermal conditions. Generally, a larger biomass implies stronger ecosystem service functions (Xu et al., 2012). We assumed a linear relationship between ecosystem service functions and biomass. Given a lack of biomass data, the forest stock volume, which could largely represent biomass, was utilised to rectify the EVC of forest ecosystem as follows:

$$
E_{1 j}{ }^{\prime}=\frac{b}{B} \times E_{1 j}
$$

where $b$ and $B$ are the average stock volumes of forest ecosystem per hectare per year in the study area and in China respectively; $E_{1 j}$ and $E_{1 j}$ ' correspond to the EVCs of forest ecosystem of ecosystem service function $j$ before and after rectification. The factor of forest rectification of the study area was 0.34 (Appendix A2) (National Bureau of Statistics of China, 2013; Forest Resources Monitoring Center of Zhejiang Province, 2007).

Third, the economic value of the standard EVC of 1 was rectified. This referred to the economic value of the natural food production of farmland with average output in China per hectare per year. However, given the difficulty in assessing this value precisely, we referred to 
the study by Xie et al. (2015) in which the value was determined as the annual net profit per unit area of major grain produced by farmland ecosystem in the study area, which was calculated as follows:

$$
D=S_{r} \times F_{r}+S_{w} \times F_{w}+S_{c} \times F_{c}
$$

where $D$ is the ESV of the standard EVC of 1 per hectare per year; $S_{r}, S_{w}$, and $S_{c}$ are the percentages of area sown with rice, wheat, and corn of the total sown area in a particular year of the study area respectively; $F_{r}, F_{w}$, and $F_{c}$ are the average net profits per hectare of rice, wheat, and corn in that year of the study area respectively. In this study, the ESV of the standard EVC of 1 was 4959.38 yuan per hectare (Appendix A3) (Price Department of the National Development and Reform Commission, 2013; Zhoushan Bureau of Statistics, 2013).

Thus, the ESV per unit area (Table 1) in Zhoushan (Appendix A4) could be calculated as follows:

$$
V C_{i j}=\left\{\begin{array}{cc}
E_{1 j} \times \frac{q}{Q} \times \frac{b}{B} \times D & i=1 \\
E_{i j} \times \frac{q}{Q} \times D & i=2,3,4
\end{array}\right.
$$

Where $V C_{i j}$ is the ESV per unit area of ecosystem service function $j$ of land-use type $i$ (yuan/ha); $i=1$ refers to forest ecosystem while $i=2,3,4$ refer to farmland, wetland, and water area ecosystems.

The total ESV of the study area was calculated as follows:

$$
E S V=\sum_{i=1}^{m} \sum_{j=1}^{n} A_{i} \times V C_{i j}
$$

Where $A_{i}$ is the interpreted area of land-use type $i$ (ha); ESV refers to the total ESV of the study area. EVC and ESV per unit area were computed with the data in 2012 to make ESVs in 2009 and 2014 comparable. When the ESV per unit area in Table 1 was multiplied by the area of each land-use

\begin{tabular}{|c|c|c|c|c|c|}
\hline $\begin{array}{l}\text { Service } \\
\text { type }\end{array}$ & Service subtype & Forest & Farmland & Wetland & Water area \\
\hline \multirow{2}{*}{$\begin{array}{l}\text { Provisioning } \\
\text { services }\end{array}$} & Food production & 643.05 & 5760.27 & 2073.70 & 3052.94 \\
\hline & $\begin{array}{l}\text { Raw materials } \\
\text { production }\end{array}$ & 5806.95 & 2246.50 & 1382.46 & 2016.09 \\
\hline \multirow{4}{*}{$\begin{array}{l}\text { Regulating } \\
\text { services }\end{array}$} & Gas regulation & 8418.13 & 4147.39 & $13,882.24$ & 2937.74 \\
\hline & $\begin{array}{l}\text { Climate } \\
\text { regulation }\end{array}$ & 7930.97 & 5587.46 & $78,051.60$ & $11,866.15$ \\
\hline & $\begin{array}{l}\text { Hydrological } \\
\text { regulation }\end{array}$ & 7969.94 & 4435.40 & $77,417.97$ & $108,120.18$ \\
\hline & Waste treatment & 3351.66 & 8006.77 & $82,947.82$ & $85,539.94$ \\
\hline \multirow[t]{2}{*}{$\begin{array}{l}\text { Supporting } \\
\text { services }\end{array}$} & $\begin{array}{l}\text { Soil formation } \\
\text { and conservation }\end{array}$ & 7833.53 & 8467.59 & $11,462.93$ & 2361.71 \\
\hline & $\begin{array}{l}\text { Biodiversity } \\
\text { maintenance }\end{array}$ & 8788.37 & 5875.47 & $21,255.38$ & $19,757.71$ \\
\hline $\begin{array}{l}\text { Cultural } \\
\text { services }\end{array}$ & $\begin{array}{l}\text { Providing } \\
\text { aesthetic value }\end{array}$ & 4053.17 & 979.25 & $27,015.64$ & $25,575.58$ \\
\hline Total & & $54,795.76$ & $45,506.10$ & $315,489.73$ & $261,228.03$ \\
\hline
\end{tabular}
type in 2009 and 2014 in Table 3, the ESV of these two periods could be acquired (Table 5).

Table 1: ESV per unit area per year (yuan/ha). 
Computation of carbon storage and sequestration value

The method of Xie et al. (2008) for evaluating ESV must be considered a crude approximation and will introduce errors depending on the type of ecosystem service and its spatial heterogeneity (Costanza et al., 1997). Specifically, the method ignores factors such as rarity, spatial configuration, size, and quality of habitat in every hectare of a given land-use type (Tallis \& Polasky, 2009). Although a few rectifications have been made, several unrectified factors still exist. This paper thus introduces the InVEST model to compensate for these limitations. InVEST was developed by the Natural Capital Project as a suite of computer-based models that can convert changes in land-use and land-cover patterns into changes in carbon storage, water availability, crop production, etc. (Nelson et al., 2010) to reveal variation in ecosystem services. It is spatially explicit and employs a tiered method to handle data availability and the state of system knowledge (Tallis \& Polasky, 2009).

In the present study, given our needs and spatial limitations, we only evaluated the carbon storage and sequestration value with the carbon module to reveal the influence of land-use and land-cover changes on the ecosystem service function of carbon sinks. The ways in which humans manage terrestrial ecosystems are critical to climate regulation (Natural Capital Project, 2015).

Table 2: Carbon pools (Mg/ha).

\begin{tabular}{|l|l|l|l|l|l|}
\hline Code & Land-use type & C_above & C_below & C_soil & C_dead \\
\hline 1 & Water area & 0.00 & 0.00 & 29.58 & 0 \\
\hline 2 & Forest & 18.49 & 4.34 & 107.64 & 2.08 \\
\hline 3 & Farmland & 3.64 & 0.36 & 82.25 & 0.77 \\
\hline 4 & Wetland & 0.00 & 0.00 & 19.78 & 0.00 \\
\hline 5 & Built-up land & 0.00 & 0.00 & 25.22 & 0.00 \\
\hline
\end{tabular}

Note: C_above, C_below, C_soil and C_dead refer to the amount of carbon stored in aboveground biomass, belowground biomass, soil, and dead organic matter per hectare respectively.

Four basic types of carbon pools were considered: the amounts of carbon stored in aboveground biomass, belowground biomass, soil, and dead organic matter. The carbon pool data (Table 2) of each land-use type were obtained from relevant literature (An, 2014; Ekoungoulou, 2014; Xi et al., 2013; Ye, 2012; Zhang et al., 2012; J. Zhang et al., 2013; Zhu et al., 2013). Combined with the land-use maps of 2009 and 2014, based on the economic value of carbon of US $\$ 66$ per ton (Tol, 2009) and the default market discount rate of $7 \%$, the carbon module produced corresponding carbon storage maps and the value of carbon sequestration. The social value of a sequestered ton of carbon is equal to the social damage avoided by sequestering the ton of carbon into the atmosphere (Stern, 2007; Tol, 2005). According to the calculation results, the average carbon density of these two years was $90.58 \mathrm{Mg} / \mathrm{ha}$, which was similar to the result of the study by Lin (2015) concerning Zhoushan of $93.77 \mathrm{Mg} / \mathrm{ha}$ in 2010 . This slight difference is mainly attributed to the different research scope and period.

\section{Changes in ecosystem services before and after establishment of the National New Area}

Land-use dynamics and land-cover changes

As shown in Table 3, forest, farmland, and built-up land were the three largest land-use types in the study area, both in 2009 and 2014. Forest occupied nearly 50\% of the total area, but the proportion of wetland and water area was merely $10.29 \%$ in 2009 and dropped to $7.79 \%$ in 2014 . 
Over the study period, built-up land, forest, and water area increased, whereas farmland and wetland decreased. Although water area showed the largest increase rate $(39.32 \%)$, its area increase was only 458.37 ha. Built-up land presented a remarkable increase in both area (2957.85 ha) and change rate $(17.40 \%)$, with an annual growth area of 591.57 ha. By contrast, farmland and wetland notably decreased by 3681.72 ha (15.39\%) and 2950.56 ha (34.46\%), with an annual decrease of 736.34 ha and 590.11 ha respectively. Variation in the forest area was relatively moderate.

Table 3: Total area and area changes of land-use types from 2009 to 2014.

\begin{tabular}{|l|l|l|l|l|}
\hline Land-use type & $\begin{array}{l}\text { Total area } \\
(\mathrm{ha})\end{array}$ & & $\begin{array}{l}\text { Change area } \\
\text { (ha) }\end{array}$ & $\begin{array}{l}\text { Change rate } \\
(\%)\end{array}$ \\
\hline & 2009 & 2014 & & \\
\hline Water area & 1165.86 & 1624.23 & 458.37 & 39.32 \\
\hline Forest & $43,848.99$ & $45,421.20$ & 1572.21 & 3.59 \\
\hline Farmland & $23,930.37$ & $20,248.65$ & -3681.72 & -15.39 \\
\hline Wetland & 8563.14 & 5612.58 & -2950.56 & -34.46 \\
\hline Built-up land & $17,001.00$ & $19,958.85$ & 2957.85 & 17.4 \\
\hline
\end{tabular}

The land-use conversion matrix (Table 4) indicates common and diversified transitions among all land-use types. The conversion replacement rates of the wetland, water area, and farmland were extremely high at $64.09 \%, 50.66 \%$, and $45.47 \%$ respectively. Almost $30 \%$ of wetland was transformed into built-up land. Farmland was mainly converted into forest and built-up land, accounting for $22.55 \%$ and $16.28 \%$ respectively. The conversion between built-up land and other land-use types (excluding wetland) was relatively balanced, whereas the conversion from wetland to built-up land was much larger than the reverse conversion. Therefore, in the study area, the area increase in built-up land was mainly derived from wetland.

Table 4: Land-use conversion matrix from 2009 to 2014 (ha/\%).

\begin{tabular}{|l|l|l|l|l|l|}
\hline 2009 & 2014 & & & & \\
\hline & Water area & Forest & Farmland & Wetland & Built-up land \\
\hline $\begin{array}{l}\text { Water } \\
\text { area }\end{array}$ & $\begin{array}{l}\mathbf{5 7 5 . 1 9} \\
\mathbf{( 4 9 . 3 4 )}\end{array}$ & $129.87(11.14)$ & $222.93(19.12)$ & $27.72(2.38)$ & $208.44(17.88)$ \\
\hline Forest & $\begin{array}{l}165.42 \\
(0.38)\end{array}$ & $\begin{array}{l}\mathbf{3 8 , 3 3 3 . 7 0} \\
\mathbf{( 8 7 . 4 2 )}\end{array}$ & $3113.64(7.10)$ & $253.89(0.58)$ & $1681.83(3.84)$ \\
\hline Farmland & $\begin{array}{l}494.01 \\
(2.06)\end{array}$ & $\begin{array}{l}5397.30 \\
(22.55)\end{array}$ & $\begin{array}{l}\mathbf{1 3 , 0 4 8 . 1 1} \\
\mathbf{( 5 4 . 5 3 )}\end{array}$ & $830.52(3.47)$ & $\begin{array}{l}3896.10 \\
(16.28)\end{array}$ \\
\hline Wetland & $\begin{array}{l}107.64 \\
(1.26)\end{array}$ & $221.67(2.59)$ & $336.51(3.93)$ & $\begin{array}{l}\mathbf{3 0 7 4 . 6 7} \\
\mathbf{( 3 5 . 9 1 )}\end{array}$ & $\begin{array}{l}2352.42 \\
(27.47)\end{array}$ \\
\hline $\begin{array}{l}\text { Built-up } \\
\text { land }\end{array}$ & $\begin{array}{l}265.32 \\
(1.56)\end{array}$ & $1103.67(6.49)$ & $\begin{array}{l}3437.10 \\
(20.22)\end{array}$ & $\begin{array}{ll}574.65(3.38) \\
\mathbf{1 0 , 8 2 1 . 4 2} \\
\mathbf{( 6 3 . 6 5 )}\end{array}$ \\
\hline
\end{tabular}

Note: The study area is surrounded by ocean. Given the variation in tides and reclamation projects, the land area is not a constant; slight conversion between the land and ocean exists, particularly for the wetland. This study highlights the terrestrial region of islands; thus, we did not include the conversion data of oceans in this table. 
Notably, from the perspective of spatial distribution of land-use conversion (Figure 2), the occupation of wetland by built-up land concentrated in the northern and southeastern coastal areas of Zhoushan Island and islands in Putuo District, such as Zhujiajian, Xiazhi, and Liuheng. Therefore, coastal mud flat resources were substantially developed and utilised over the study period.
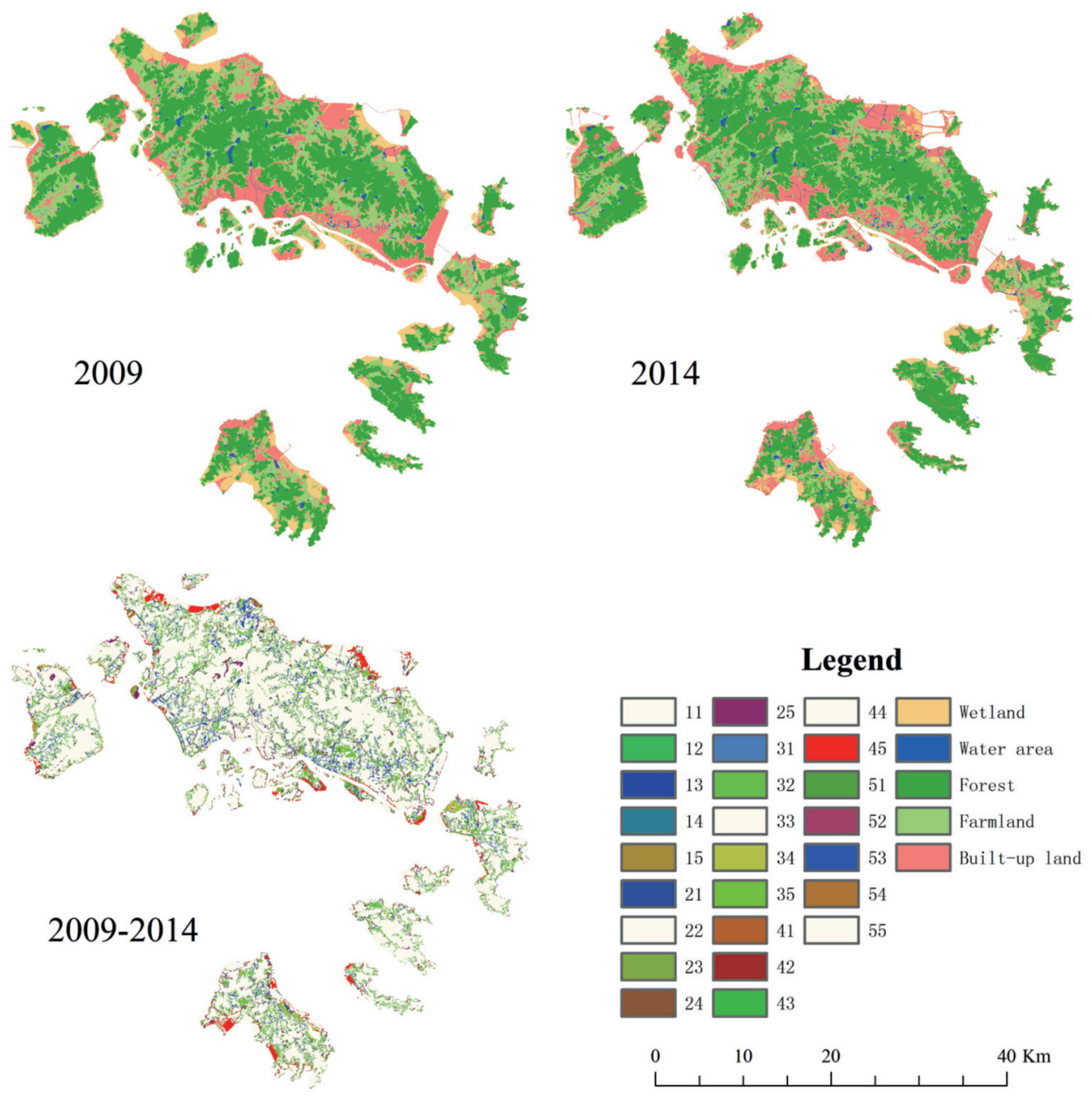

Figure 2: Land-use maps and spatial distribution of land-use conversion from 2009 to 2014: Numbers 1-5 represent water area, forest, farmland, wetland, and built-up land. Except for '11', '22', '33', '44' and ' 55 ', the codes in the legend represent land use conversions. '12', '13', '14', '15' indicate the conversions from water area to forest, farmland, wetland, and built-up land. '21', '23', '24', '25' indicate the conversions from forest to water area, farmland, wetland, and built-up land. '31', '32', ' 34 ', ' 35 ' indicate the conversions from farmland to water area, forest, wetland, and built-up land. '41', ' 42 ', ' 43 ', ' 45 ' indicate the conversions from wetland to water area, forest, farmland, and built-up land. ' 51 ', '52', '53', '54' indicate the conversions from built-up land to water area, forest, farmland and wetland.

Spatiotemporal changes in ESV

Table 5 shows the ESV and its variation in each ecosystem service function and land-use type from 2009 to 2014. The total ESV decreased from 6.50 billion yuan in 2009 to 5.61 billion yuan in 2014, with a gross reduction rate of $13.74 \%$ and an annual reduction of 0.18 billion yuan. Given the variation in land-use types, the ESV of each ecosystem followed a similar trend: the ESVs of forest and water area ecosystems increased, whereas those of farmland and wetland ecosystems decreased. The change rate of each ecosystem and its service function was the same as that of corresponding land-use type. Forest and wetland ecosystems presented higher ESV, accounting 
for approximately 40\% and 35\% respectively of the total ESV. Although wetland occupied less than $10 \%$ of the land cover, the highest ESV per unit area contributed to its large ESV.

Table 5: ESV and its variation in each ecosystem service function and land-use type from 2009 to 2014 (a hundred million yuan).

\begin{tabular}{|c|c|c|c|c|c|c|}
\hline Ecosystem service & Forest & Farmland & Wetland & Water area & Total & \\
\hline & $2009 / 2014$ & $2009 / 2014$ & $2009 / 2014$ & $2009 / 2014$ & $2009 / 2014$ & $\begin{array}{l}\text { Change } \\
\text { rate }(\%)\end{array}$ \\
\hline Food production & $0.28 / 0.29$ & $1.38 / 1.17$ & $0.18 / 0.12$ & $0.04 / 0.05$ & $1.87 / 1.62$ & -13.30 \\
\hline $\begin{array}{l}\text { Raw materials } \\
\text { production }\end{array}$ & $2.55 / 2.64$ & $0.54 / 0.45$ & $0.12 / 0.08$ & $0.02 / 0.03$ & $3.23 / 3.20$ & -0.71 \\
\hline Gas regulation & $3.69 / 3.82$ & $0.99 / 0.84$ & $1.19 / 0.78$ & $0.03 / 0.05$ & $5.91 / 5.49$ & -7.05 \\
\hline $\begin{array}{l}\text { Climate } \\
\text { regulation }\end{array}$ & $3.48 / 3.60$ & $1.34 / 1.13$ & $6.68 / 4.38$ & $0.14 / 0.19$ & $11.64 / 9.31$ & -20.02 \\
\hline $\begin{array}{l}\text { Hydrological } \\
\text { regulation }\end{array}$ & $3.49 / 3.62$ & $1.06 / 0.90$ & $6.63 / 4.35$ & $1.26 / 1.76$ & $12.45 / 10.62$ & -14.68 \\
\hline Waste treatment & $1.47 / 1.52$ & $1.92 / 1.62$ & $7.10 / 4.66$ & $1.00 / 1.39$ & $11.49 / 9.19$ & -20.00 \\
\hline $\begin{array}{l}\text { Soil formation } \\
\text { and conservation }\end{array}$ & $3.43 / 3.56$ & $2.03 / 1.71$ & $0.98 / 0.64$ & $0.03 / 0.04$ & $6.47 / 5.95$ & -7.97 \\
\hline $\begin{array}{l}\text { Biodiversity } \\
\text { maintenance }\end{array}$ & $3.85 / 3.99$ & $1.41 / 1.19$ & $1.82 / 1.19$ & $0.23 / 0.32$ & $7.31 / 6.70$ & -8.41 \\
\hline $\begin{array}{l}\text { Providing } \\
\text { aesthetic value }\end{array}$ & $1.78 / 1.84$ & $0.23 / 0.20$ & $2.31 / 1.52$ & $0.30 / 0.42$ & $4.62 / 3.97$ & -14.11 \\
\hline Total & $24.03 / 24.89$ & $10.89 / 9.21$ & $27.02 / 17.71$ & $3.05 / 4.24$ & $64.98 / 56.05$ & -13.74 \\
\hline Change rate $(\%)$ & 3.59 & -15.39 & -34.46 & 39.32 & 1 & 1 \\
\hline
\end{tabular}

Hydrological regulation, climate regulation, and waste treatment were three dominant ecosystem service functions in the study area, accounting for over $50 \%$ of the total ESV. Forest ecosystem played a vital role in providing various ecosystem services. The larger decrease in the ESVs of regulating and cultural services accounted for $16.56 \%$ and $14.11 \%$ respectively, whereas the relatively smaller decrease in the ESVs of the supporting and provisioning services accounted for a corresponding $8.21 \%$ and $5.34 \%$ (Figure 3).

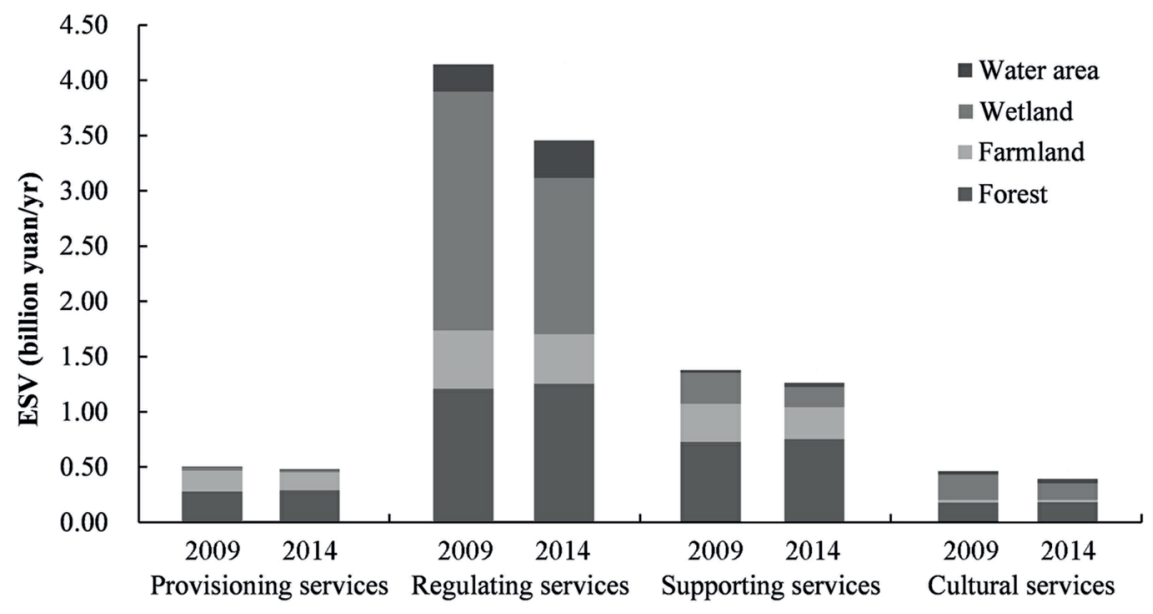

Figure 3: ESV variation in each ecosystem service from 2009 to 2014. 
Obviously, the ESV of all the ecosystem service functions consistently decreased, with the regulating service functions of climate regulation, waste treatment, and hydrological regulation having the greatest reduction rates of $20.02 \%, 20.00 \%$, and $14.68 \%$ respectively. The decline in wetland and farmland areas as well as the expansion of built-up land may well explain the ESV reduction in these ecosystem services.

Table 6 shows the spatial difference of ESV from 2009 to 2014. Both districts presented a decreasing trend of the total ESV by $12.14 \%$ and $16.30 \%$ respectively. The total ESV and ESV per unit area of the central urban area were approximately $50 \%$ and $80 \%$ of those of the non-central urban area, which were ascribed to their different areas and larger proportions of land-use types with lower ESV per unit area in the central urban area. Over the study period, ecosystem service functions of the non-central urban area were more seriously damaged, with a reduction rate of $15.54 \%$ for the total ESV and $14.02 \%$ for the ESV per unit area. This effect was probably caused by recent intensive constructions in the non-central urban area.

Table 6: Variation in ESV and ESV per unit area of each island and region from 2009 to 2014.

\begin{tabular}{|l|l|l|l|l|l|l|}
\hline Island/region & \multicolumn{2}{|l|}{$\begin{array}{l}\text { Total ESV } \\
\text { (billion yuan) }\end{array}$} & \multicolumn{3}{l|}{ ESV per unit area (yuan/ha) } & \multicolumn{2}{l|}{ Change rate (\%) } \\
\hline & 2009 & 2014 & 2009 & 2014 & $\begin{array}{l}\text { Total } \\
\text { ESV }\end{array}$ & $\begin{array}{l}\text { ESV per } \\
\text { unit area }\end{array}$ \\
\hline Central urban area & 20.59 & 18.37 & $57,883.53$ & $52,707.42$ & -10.77 & -8.94 \\
\hline Non-central urban area & 44.25 & 37.37 & $75,097.97$ & $64,566.63$ & -15.54 & -14.02 \\
\hline Zhoushan Island & 3.36 & 2.98 & $59,514.22$ & $53,241.87$ & -11.24 & -10.54 \\
\hline Liuheng & 0.99 & 0.81 & $93,129.65$ & $78,346.58$ & -17.70 & -15.87 \\
\hline Jintang & 0.62 & 0.54 & $69,936.46$ & $62,493.69$ & -13.07 & -10.64 \\
\hline Zhujiajian & 0.48 & 0.45 & $70,959.28$ & $68,539.30$ & -7.67 & -3.41 \\
\hline Taohua & 0.32 & 0.27 & $75,685.59$ & $67,511.85$ & -14.20 & -10.80 \\
\hline Dengbu & 0.20 & 0.17 & $133,901.75$ & $117,763.68$ & -15.23 & -12.05 \\
\hline Changbai & 0.18 & 0.10 & $133,468.57$ & $81,494.57$ & -45.70 & -38.94 \\
\hline Xiazhi & 0.11 & 0.09 & $64,507.30$ & $49,652.44$ & -23.25 & -23.03 \\
\hline Putuoshan & 0.11 & 0.07 & $83,560.78$ & $57,104.40$ & -40.11 & -31.66 \\
\hline Cezi & 0.10 & 0.09 & $66,436.39$ & $61,055.50$ & -8.35 & -8.1 \\
\hline
\end{tabular}

As the largest island in the Zhoushan Archipelago, the total ESV of Zhoushan Island was over three times that of Liuheng Island (the second-ranked island). Over the study period, the total ESV and ESV per unit area of all the islands followed a decreasing trend, among which Changbai, Putuoshan, and Xiazhi presented the greatest reduction rates. On Zhoushan Island, the ESV reduction rate of the Shenjiamen subdistrict even surpassed 50\%, and the total ESV of the northern portion of the island decreased by 0.11 billion yuan, which involved a substantial amount of occupation of wetland and farmland in these areas. 
Spatiotemporal changes in carbon storage

Although this study has directly rectified the EVC of wetland ecosystem through area rectification, it is still insufficiently thorough given the great variation of area and ESV in the wetland, particularly for its regulating services. Climate regulation was one of the most dominant ecosystem service functions in the study area, accounting for approximately $17 \%$ of the total ESV. However, it was seriously damaged, and its ESV declined by more than $20 \%$ over the study period. It is known that carbon storage is closely correlated with climate regulation. This study thus introduced the carbon module in the InVEST model to reevaluate in a more precise and spatial manner the value and variation in this important function, as an indirect rectification of wetland ecosystem. As shown by the carbon pools data (Table 2), the carbon density of forest ecosystem was greatest, followed by those of farmland and water area ecosystems. Given that coastal mud flat was the main type of wetland in the study area, the carbon density of wetland ecosystem was relatively smaller, compared with its much larger ESV per unit area.

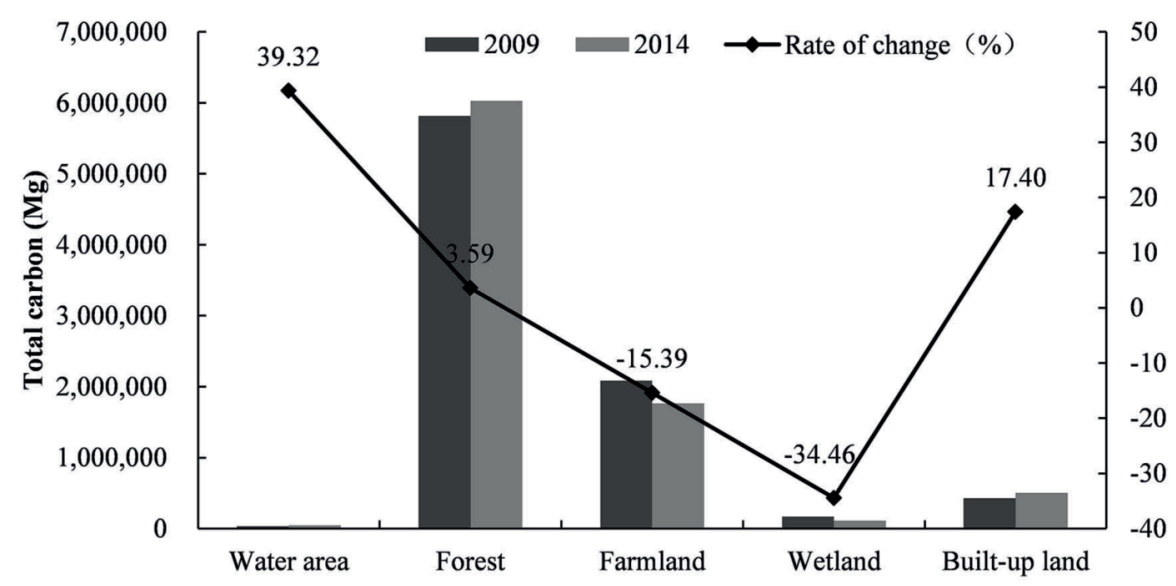

Figure 4: Variation in carbon storage of each ecosystem from 2009 to 2014.

Over the study period, the total carbon storage decreased from 8,536,276.40 $\mathrm{Mg}$ to 8,453,993.90 Mg, thereby releasing $82,282.50 \mathrm{Mg}$ carbon, which was equivalent to a total loss of US $\$ 4,765,076.88$ and an annual loss of US $\$ 953,015.38$. The release rate was $0.96 \%$. Forest and farmland ecosystems presented greater carbon storage, accounting for approximately $70 \%$ and $20 \%$ respectively. In terms of the change rate (Figure 4), a significant increase in the carbon storage of water area and built-up land ecosystems existed but was accompanied by a significant decrease in that of wetland and farmland ecosystems. These findings were consistent with the variation in land use. As the farmland ecosystem had the greatest carbon release of 320,724.63 $\mathrm{Mg}$, the encroachment on farmland by built-up land may be the main reason for carbon release, which consequently impaired the ecosystem service function of climate regulation. The slight increase in the forest area helped maintain the release rate at such a low level.

Figure 5 and Table 7 show the spatial pattern of carbon sequestration from 2009 to 2014. Both districts released carbon, but Putuo presented a much higher release rate of $1.81 \%$. Given its large forest area, Zhoushan Island achieved the largest carbon storage, which was nearly six times that of second-ranked Liuheng Island. Most of the islands released carbon. Changbai presented the largest releasing rate of 8.12\%, and Liuheng, Jintang, and Zhujiajian released carbon greater than 20,000 Mg. Whether an island or region sequestered or released carbon depended on its land-use conversions, which influenced the climate regulation ecosystem service function. 

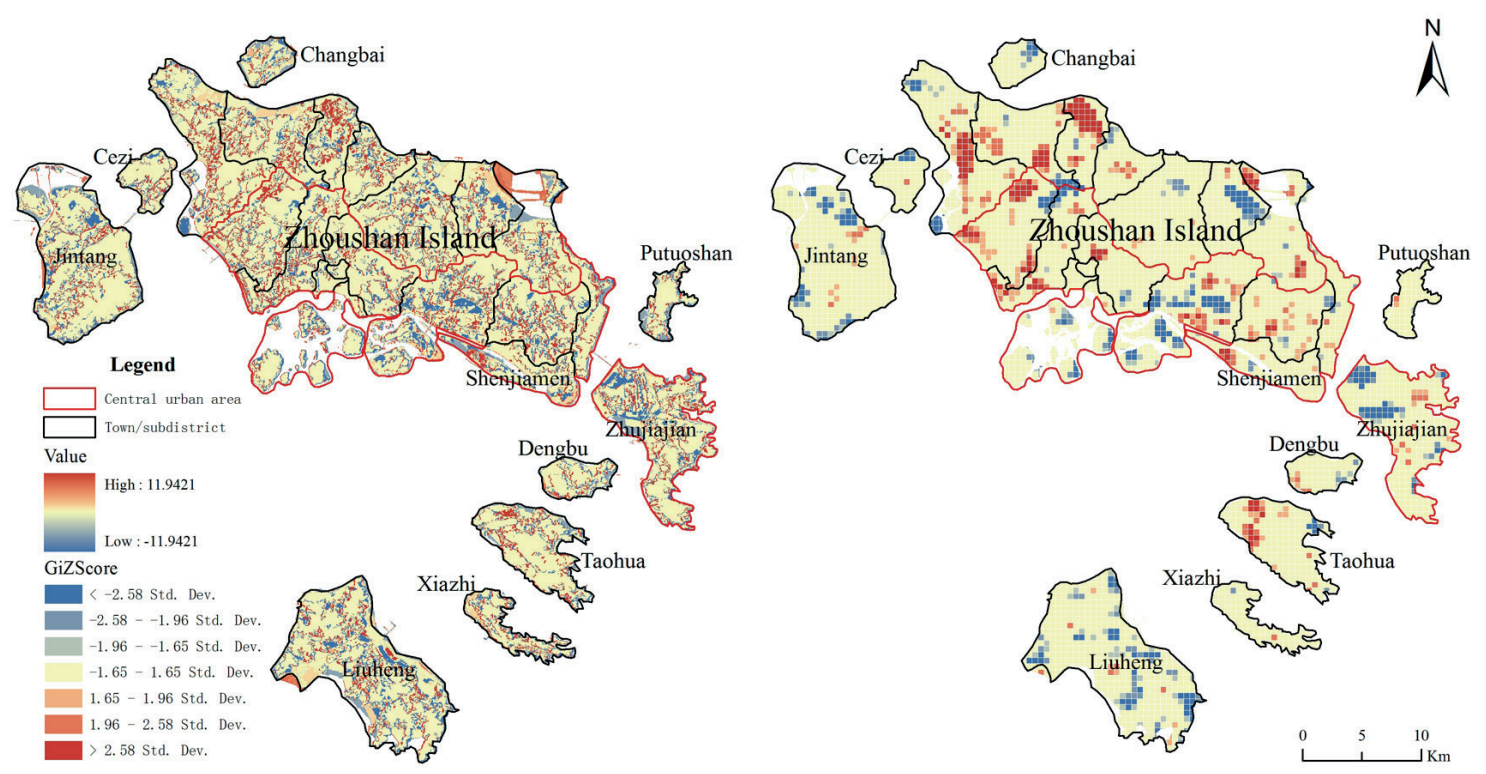

Figure 5: Spatial distribution and hotspot analysis of carbon sequestration from 2009 to 2014 .

Table 7: Variation in carbon storage and sequestration value of each island and region from 2009 to 2014.

\begin{tabular}{|l|l|l|l|l|l|}
\hline Island/region & \multicolumn{2}{|l|}{ Carbon storage $(\mathrm{Mg})$} & $\begin{array}{l}\text { Sequestration } \\
\text { carbon }(\mathrm{Mg})\end{array}$ & $\begin{array}{l}\text { Sequestration } \\
\text { rate }(\%)\end{array}$ & $\begin{array}{l}\text { Sequestration } \\
\text { value (\$) }\end{array}$ \\
\hline & 2009 & 2014 & & & \\
\hline $\begin{array}{l}\text { Central urban } \\
\text { area }\end{array}$ & $3,112,440$ & $3,077,500$ & $-34,940$ & -1.12 & $-2,893,200$ \\
\hline $\begin{array}{l}\text { Non-central } \\
\text { urban area }\end{array}$ & $5,423,280$ & $5,373,320$ & $-49,960$ & -0.92 & $-2,023,820$ \\
\hline Changbai & 94,058 & 86,424 & -7634 & -8.12 & $-442,108$ \\
\hline Liuheng & 875,746 & 829,428 & $-46,318$ & -5.29 & $-2,682,310$ \\
\hline Zhujiajian & 593,580 & 568,881 & $-24,699$ & -4.16 & $-1,430,380$ \\
\hline Jintang & 874,613 & 845,902 & $-28,711$ & -3.28 & $-1,662,700$ \\
\hline Cezi & 144,678 & 142,141 & -2537 & -1.75 & $-146,893$ \\
\hline Putuoshan & 130,319 & 128,049 & -2270 & -1.74 & $-131,458$ \\
\hline Dengbu & 128,674 & 127,144 & -1530 & -1.19 & $-88,652$ \\
\hline Xiazhi & 175,510 & 173,577 & -1933 & -1.10 & $-111,941$ \\
\hline Zhoushan & $5,072,540$ & $5,095,520$ & 22,980 & 0.45 & $1,330,950$ \\
\hline Taohua & 446,003 & 453,747 & 7744 & 1.74 & 448,475 \\
\hline
\end{tabular}




\section{Potential effects of the National New Area development policy on island ecosystem services}

The implementation of the National New Area policy caused a huge demand for construction land. However, given the scarce land resources in the archipelago, people preferred to occupy farmland, wetland, and unused land, thereby altering the ecosystem patterns and affecting the ecosystem services. The transformation of the developmental orientation caused rapid economic development and urbanisation in Zhoushan but also had an overall influence on ecosystem services. Simultaneously, specific kinds of spatial planning practices led to spatial differences in the declines in ESV and carbon storage. Preferential policies guaranteed Zhoushan's development but further influenced island ecosystem services, particularly for the differentiated land-use policy.

\section{Impacts of transforming developmental orientation}

The National New Area policy specified and enhanced Zhoushan's developmental orientation. Before Zhoushan was established as a National New Area, its urban development planning for 2000 to 2020 only positioned this region as an ocean and marine cultural city with a developed economy. However, after the establishment of the New Area, its development became part of national strategy. Thus, the orientation was transformed into three aspects: a pilot area for marine economic development in Zhejiang; an important economic growth pole of the Yangtze River Delta; and an experimental zone for comprehensive marine development, which involves many aspects, such as transforming and upgrading the marine industrial structure, optimising the layout of the port industry, education and introducing skills, and protecting the marine environment on a scientific basis. These three strategic orientations raised Zhoushan's development goals and construction intensity. The number of provincial key construction projects in Zhoushan increased from 19 in 2011 to 44 in 2015. Since 2013, 100 major projects have been implemented annually, mainly in Dinghai and Putuo, with an annual investment of up to approximately 50 billion yuan. Leading industries were also transformed from agriculture and fishery to non-agricultural industries, such as ports, logistics, shipbuilding, manufacturing of marine engineering equipment, marine tourism, and pelagic fishery.

Table 8: Variation in ESV in response to socioeconomic drivers and land-use changes.

\begin{tabular}{|l|l|l|l|}
\hline Index & 2009 & 2014 & Change rate (\%) \\
\hline ESV (billion yuan) & 6.50 & 5.61 & -13.69 \\
\hline Carbon storage (Mg) & $8,536,276.40$ & $8,453,993.90$ & $-0.96 \%$ \\
\hline GDP (billion yuan) & 41.85 & 68.33 & 63.29 \\
\hline ESV/GDP (\%) & 15.53 & 8.21 & -47.14 \\
\hline Total population (person) & $1,063,000$ & $1,146,000$ & 7.81 \\
\hline Area of built-up land (ha) & $17,001.00$ & $19,958.85$ & 17.40 \\
\hline
\end{tabular}

Note: Given that ESVs in 2009 and 2014 were both computed based on the price level in 2012, the corresponding GDPs in 2009 and 2014 were also adjusted, with the GDP in 2012 set as the baseline, using data from the National Bureau of Statistics of China and the Zhoushan Bureau of Statistics. Area of built-up land was derived by interpreting remote sensing images.

Such transformation of developmental orientation caused rapid economic development and urbanisation in Zhoushan. Cargo throughput of the Ningbo-Zhoushan port surpassed Shanghai for the first time in 2012, and the gap widened to 34 million tons in 2013. In addition, Zhoushan's per capita GDP exceeded the average level of Zhejiang Province in 2005, and since 2011 this gap 
has gradually widened: The per capita GDP of Zhejiang Province was only $81.89 \%$ that of Zhoushan in 2014. However, with the growth of GDP, total population, and built-up land area, the ESV and carbon storage of Zhoushan declined, and the ratio of ESV to GDP decreased by nearly $50 \%$, as shown in Table 8. These results indicate that substantial economic growth, population growth, and expansion of built-up land exerted negative effects on Zhoushan's ecosystem services.

Specific kinds of spatial planning producing spatially distinct damage to island ecosystem services

The National New Area policy specified Zhoushan's developmental pattern. Zhoushan Island is set as the city center. Changbai, Cezi, and Jintang are located in the western development belt, which is the main region for industrial development and urbanisation. Liuheng, Xiazhi, Taohua, Dengbu, Zhujiajian, and Putuoshan are located in the eastern development belt, with the themes of marine recreational industry and maritime garden city. Over the study period, the total population and population engaged in the secondary sector on Zhoushan Island increased by $6.04 \%$ and $5.25 \%$ respectively and the number of industrial enterprises in the western development belt increased from 625 in 2009 to 788 in 2014. In the western development belt, farmland and wetland decreased by $16.25 \%$ and $41.23 \%$, with a large increase of $41.23 \%$ in built-up land, while in the eastern development belt, farmland and wetland decreased by $26.91 \%$ and $29.11 \%$, with a large increase of $36.01 \%$ in built-up land. Under such influence, the total ESV and ESV per unit area of the western development belt declined by $19.04 \%$ and $16.22 \%$ respectively, which were higher than those of the eastern development belt (16.20\% and $13.17 \%$ respectively). The situation was identical for the carbon release rate: $3.49 \%$ in the west and $2.94 \%$ in the east. Furthermore, the ESVs of regulating and cultural services of the western development belt declined by $22.27 \%$ and $19.95 \%$ respectively, which were higher decreases than those of the eastern development belt (18.17\% and $15.46 \%$ respectively). It is clear that the impairment in ecosystem services was more serious in the western development belt.

Moreover, the new developmental pattern of 'south for life, center for ecology, and north for production' was implemented on Zhoushan Island. With people mainly migrating to the southern part of the island, urban areas expanded. The northern marine industrial belt, located within the range of Xiaosha and Zhanmao, is a pilot area for industrial transformation and an upgrading and agglomeration area for the development of new marine industries. Over the study period, the population engaged in the secondary sector of this region increased remarkably by $47.37 \%$. Farmland and wetland decreased by $12.14 \%$ and $27.58 \%$ while built-up land increased by $14.86 \%$. However, given the exploitation of ports, piers, and industrial land along the northern shoreline, the ESV in this area decreased by 0.11 billion yuan, and the ecosystem service functions of climate regulation and waste treatment were seriously impaired, with decrease rates of $12.01 \%$ and $12.68 \%$ respectively.

Besides Zhoushan Island, the islands of Liuheng, Jintang, and Changbai presented the largest declines in total ESV, which were $0.18,0.08$, and 0.08 billion yuan respectively. The carbon release rates of these three islands were also greater than those of the other islands. Liuheng and Jintang are the two islands closest to the mainland in the study area. Liuheng is the central town in the eastern development belt, and Jintang is a key town in the west, where the container port coastlines are mainly distributed. Given the principle of coordinated and integrated development for land and sea, these two islands suffered greater anthropogenic interference. Over the study period, the population engaged in the secondary and tertiary sectors on Liuheng and Jintang increased by $17.43 \%$ and $19.01 \%$ respectively. On Liuheng, farmland and wetland decreased by $24.41 \%$ and $27.10 \%$ respectively, built-up land increased by $14.86 \%$, and four ecosystem services suffered severe impairment with decrease rates over $12 \%$. On Jintang, farmland and wetland decreased by $19.19 \%$ and $33.74 \%$, built-up land increased by $41.71 \%$, and the regulating and cultural services suffered more serious impairment with decrease rates of $15.22 \%$ and $12.48 \%$ respectively. Changbai and Liuheng are planned to prioritize the development of vital marine industries, such as shipbuilding and manufacturing of marine engineering equipment. Despite its extremely small land area, the advantageous location and abundant resources of Changbai led to 
its rapid development and serious impairment in terms of ecosystem services, wherein the total ESV and ESV per unit area declined by $45.70 \%$ and $38.94 \%$ respectively, and the carbon release rate reached a maximum of $8.12 \%$. Furthermore, given the slight variation in forest on other islands, forest in Changbai declined by $16.03 \%$, and wetland also reached the greatest decrease rate of $58.76 \%$, with built-up land having the largest increase rate of $72.74 \%$. As a result, seven of nine ecosystem service functions' decrease rates of ESV were over 30\%, with the function of climate change having the greatest reduction rate of $51.91 \%$.

Table 9: The change rate of area/ESV of each land-use type/ecosystem service function in each region/island from 2009 to 2014 (\%).

\begin{tabular}{|l|l|l|l|l|l|l|}
\hline $\begin{array}{l}\text { Land-use type/ } \\
\text { ecosystem service } \\
\text { function }\end{array}$ & $\begin{array}{l}\text { Western } \\
\text { development } \\
\text { belt }\end{array}$ & $\begin{array}{l}\text { Eastern } \\
\text { development } \\
\text { belt }\end{array}$ & $\begin{array}{l}\text { Northern } \\
\text { marine } \\
\text { industrial } \\
\text { belt }\end{array}$ & Liuheng & Jintang & $\begin{array}{l}\text { Chang } \\
\text { bai }\end{array}$ \\
\hline Forest & -0.31 & 4.54 & 5.99 & -0.80 & 1.04 & -16.03 \\
\hline Farmland & -16.25 & -26.91 & -12.14 & -24.41 & -19.19 & 11.63 \\
\hline Wetland & -41.23 & -29.11 & -27.58 & -27.10 & -33.74 & -58.75 \\
\hline Water area & 62.00 & 73.64 & 38.13 & 52.71 & 48.42 & 94.78 \\
\hline Built-up land & 41.23 & 36.01 & 14.86 & 52.20 & 41.70 & 72.74 \\
\hline Food production & -15.27 & -21.54 & -9.72 & -20.54 & -15.95 & -13.21 \\
\hline $\begin{array}{l}\text { Raw materials } \\
\text { production }\end{array}$ & -4.13 & -2.29 & 2.02 & -6.64 & -2.99 & -17.85 \\
\hline Gas regulation & -11.60 & -9.76 & -2.09 & -13.53 & -7.93 & -37.03 \\
\hline Climate regulation & -26.22 & -20.89 & -12.01 & -21.81 & -18.92 & -51.91 \\
\hline $\begin{array}{l}\text { Hydrological } \\
\text { regulation }\end{array}$ & -20.24 & -16.14 & -7.42 & -16.86 & -12.71 & -48.14 \\
\hline Waste treatment & -25.70 & -21.11 & -12.68 & -20.33 & -18.36 & -49.81 \\
\hline $\begin{array}{l}\text { Soil formation and } \\
\text { conservation }\end{array}$ & -11.74 & -11.95 & -3.72 & -14.80 & -9.51 & -30.11 \\
\hline $\begin{array}{l}\text { Biodiversity } \\
\text { maintenance }\end{array}$ & -12.88 & -11.35 & -3.19 & -14.19 & -8.82 & -38.27 \\
\hline $\begin{array}{l}\text { Providing aesthetic } \\
\text { value }\end{array}$ & -19.95 & -15.46 & -6.62 & -17.16 & -12.48 & -49.03 \\
\hline Total ESV & -18.99 & -16.16 & -7.06 & -17.67 & -13.03 & -45.68 \\
\hline
\end{tabular}

Preferential policies further influencing island ecosystem services

Since the establishment of the National New Area, Zhoushan has enjoyed various resources and preferential policies, which have guaranteed its development but further influenced island 
ecosystem services. To improve the administrative system and coordination among its administrative divisions, the State Council set up the Zhoushan Archipelago New Area Administrative Committee and even endowed the committee with provincial management rights to enlarge its autonomy with regard to development. In addition, more convenient approval procedures were established for national and provincial key projects utilizing marine areas. Priorities in financial and tax policies comprehensively ensured rapid development and construction.

Among the preferential policies, the differentiated land-use policy demonstrated a direct influence on island ecosystem services. This policy prioritized land use for marine projects. Farmland occupied by national and provincial projects, which could not be supplemented in other cities in Zhejiang Province after evaluation, could be supplemented in provinces elsewhere in China. This facilitated encroachment upon the archipelago's farmland, thereby affecting its ecosystem services. This increased the importance of sound planing and development policy in Zhoushan to offset the negative impacts of provincial-level policies. Moreover, to satisfy the great demand for land, land reclamation projects were heavily promoted, particularly on Zhoushan Island, Jintang, Liuheng, and Zhujiajian. The alongshore method of coastal reclamation mainly used in the construction of urban and industrial areas is today prevalent in Zhoushan Archipelago, due to its low difficulty and construction costs. However, this method has led to a rapid shrinkage of coastal wetland, thereby damaging its regulating services.

\section{Discussion and conclusion}

This study revealed the spatiotemporal changes in land use, ESV, and carbon storage of Dinghai and Putuo in the Zhoushan Archipelago before and after the establishment of the National New Area, and it comprehensively analyzed the potential effects of this national policy on island ecosystem services.

The results showed that the total ESV and carbon storage declined by $13.69 \%$ and $0.96 \%$ respectively, with a remarkable increase in built-up land (17.40\%) and decrease in farmland $(15.39 \%)$ and wetland (34.46\%). The ESV of all the ecosystem service functions consistently decreased, with the regulating service functions of climate regulation, waste treatment, and hydrological regulation having the greatest reduction rates. The encroachments upon farmland and wetland by built-up land in the northern and southeastern coastal areas of Zhoushan Island and on the islands in Putuo District were the main causes for the impairment in ecosystem services and carbon release. Forest ecosystem played a vital role in providing various ecosystem services and carbon sequestration because of its large area, high ESV per unit area, and carbon density.

Islands are relatively closed, fragile, and sensitive to external interference. Under the influence of the National New Area policy, the land-use structure in Zhoushan was altered, thereby changing its ecosystem patterns and further impairing ecosystem services. Although the central and local governments have begun taking measures to protect sensitive areas in Zhoushan, we still recommend some preliminary suggestions based on the results obtained here in order to pursue sustainable use of the archipelago. First, given its large forest area and strong ecosystem service functions, the government should pay more attention to forest protection on both small and large islands, in terms of both quality and structure. Second, other land reclamation methods, such as the offshore method of artificial island reclamation, which is suitable for relatively independent industrial bases for logistics, petrochemical, and other industries, can be adopted to partly replace the alongshore method. The balance between conservation and exploitation of coastal wetland should be carefully considered in the future. Finally, although the ecosystem service valuation is advantageous, and a growing number of case study-based publications have proved its usefulness, this approach is seldom used in practice (Wu et al., 2013). ESV should be given adequate weight in land-use decision-making processes for islands. The ESV/GDP relationship could be a good tool for assessing the tradeoff between island development and ecological conservation. If GDP goes up, a net positive variation of the ESV/GDP value means a real improvement in ecosystem services along with the development, which achieves a win-win result. 
Several limitations remain. First, our estimate of ESV is limited by data and methods; it thus represents a crude measure and is likely an underestimation. The land-use classification was too rough to acquire more precise results. The maritime ESV was somewhat neglected, given that the boundary between the coast and shallow seas can be difficult to determine using Google Maps, and the derivation of the coastal wetland may result in an underestimated ESV. We also ignored the ESV of built-up land, which might exert a positive or negative effect on the environment. Given the EVC we adopted, just nine ecosystem services were included, with services such as pollination and gene resources being ignored. We conducted EVC rectifications for area and forest ecosystem but did not rectify other ecosystems more precisely. Second, given a lack of thorough carbon density data, we may be underestimating carbon storage. Third, we only comprehensively discussed the potential effects of the national development policy on island ecosystem services; we did not include other factors and carry out a thorough quantitative analysis. Although the absolute ESV and carbon storage may be insufficiently accurate, we are primarily interested in the dynamics of ecosystem services over the study period.

In the future, focus should be placed on more precise measurements of island ESV, including the marine zone and a thorough quantitative analysis of the effects of development policies. The cost-benefit analysis of increased economic development and loss of ecosystem services in islands is also well worth exploring.

\section{Acknowledgements}

This work was supported by the Key Program of the National Social Science Foundation of China (No. 14AZD124), National Natural Science Foundation of China (No.41671533; 51508498), and the Fundamental Research Funds for the Central Universities (2016XZZX004-02).

\section{References}

Ai, X.A., \& Hong, T. (2015). Evaluation and Analysis of Ecosystem Services Value in Xiamen Island. Chinese Agricultural Science Bulletin, 31(16), 194-200.

Alcamo, J., \& Bennett, E. (2003). Ecosystems and human well-being. Millennium Ecosystem Assessment (MA). Washington, DC: Island Press.

An, L. (2014). Studies on the soil series database and its preliminary application in Zhejiang Province. (Masters Dissertation), Zhejiang A\&F University, Lin'an, China.

Angeler, D.G., \& Alvarez-Cobelas, M. (2005). Island biogeography and landscape structure: Integrating ecological concepts in a landscape perspective of anthropogenic impacts in temporary wetlands. Environmental Pollution, 138(3), 420-424. https://doi.org/10.1016/j.envpol.2005.04.020

Aretano, R., Petrosillo, I., Zaccarelli, N., Semeraro, T., \& Zurlini, G. (2013). People perception of landscape change effects on ecosystem services in small Mediterranean islands: A combination of subjective and objective assessments. Landscape and Urban Planning, 112, 63-73. https://doi.org/10.1016/j.landurbplan.2012.12.010

Braat, L.C., \& de Groot, R. (2012). The ecosystem services agenda: Bridging the worlds of natural science and economics, conservation and development, and public and private policy. Ecosystem Services, 1(1), 4-15. https://doi.org/10.1016/j.ecoser.2012.07.011

Chen, J., Pan, D., Mao, Z., Chen, N., Zhao, J., \& Liu, M. (2013). Land-cover reconstruction and change analysis using multisource remotely sensed imageries in Zhoushan Islands since 1970. Journal of Coastal Research, 30, 272-282.

Chen, Z., \& Zhang, X. (2000). Value of ecosystem services in China. Chinese Science Bulletin, 45(10), 870-876. https://doi.org/10.1007/BF02886190 
Costanza, R., d'Arge, R., de Groot, R., Faber, S., Grasso, M., Hannon, B., Limburg, K., Naeem, S., O’Neill, R., Paruelo, J., Raskin, R., Sutton, P., \& Van den Belt, M. (1997). The value of the world's ecosystem services and natural capital. Nature, 387, 253-260. https://doi.org/10.1038/387253a0

Costanza, R., de Groot, R., Sutton, P., van der Ploeg, S., Anderson, S.J., Kubiszewski, I., Farber, S., \& Turner, R.K. (2014). Changes in the global value of ecosystem services. Global Environmental Change, 26, 152-158. https://doi.org/10.1016/j.gloenvcha.2014.04.002

Costanza, R., \& Kubiszewski, I. (2012). The authorship structure of 'ecosystem services' as a transdisciplinary field of scholarship. Ecosystem Services, 1(1), 16-25. https://doi.org/10.1016/j.ecoser.2012.06.002

Curtis, I.A. (2004). Valuing ecosystem goods and services: A new approach using a surrogate market and the combination of a multiple criteria analysis and a Delphi panel to assign weights to the attributes. Ecological Economics, 50(3), 163-194. https://doi.org/10.1016/j.ecolecon.2004.02.003

Daily, G.C. (1997). Nature's services: Societal dependence on natural ecosystem. Washington, DC: Island Press.

Daily, G.C., Söderqvist, T., Aniyar, S., Arrow, K., Dasgupta, P., Ehrlich, P.R., Folke, C., Jansson, A., Jansson, B.-O., \& Kautsky, N. (2000). The value of nature and the nature of value. Science, 289(5478), 395-396. https://doi.org/10.1126/science.289.5478.395

Ehrlich, P.R., \& Ehrlich, A. (1981). Extinction: The cause and consequences of the disappearance of species. New York: Random House.

Ekoungoulou, R. (2014). Evaluation of carbon stocks in above- and below-ground biomass in Lesio-Louna forest of Congo. (Masters Dissertation), Beijing Forestry University, Beijing, China.

Farber, S.C., Costanza, R., \& Wilson, M.A. (2002). Economic and ecological concepts for valuing ecosystem services. Ecological Economics, 41(3), 375-392. https://doi.org/10.1016/S0921$\underline{8009(02) 00088-5}$

Forest Resources Monitoring Center of Zhejiang Province. (2007). Regional distribution of forest resources. Retrieved from http://www.zjfr.cn/forestry/forest/archives/2007/11/23/6737/

Freeman III, A.M., Herriges, J.A., \& Kling, C.L. (2014). The measurement of environmental and resource values: Theory and methods. London \& New York: Routledge.

Janssen, L.L., \& Vanderwel, F.J. (1994). Accuracy assessment of satellite derived land-cover data: A review. Photogrammetric Engineering and Remote Sensing, 60(4), 418-426. https://doi.org/10.1093/acprof:oso/9780199588992.001.0001

Lin, T., Xue, X., Shi, L., \& Gao, L. (2013). Urban spatial expansion and its impacts on island ecosystem services and landscape pattern: A case study of the island city of Xiamen, Southeast China. Ocean \& Coastal Management, 81, 90-96. https://doi.org/10.1016/j.ocecoaman.2012.06.014

Lin, Y. (2015). Land-use change and ecosystem services evaluation in the islands city, based on remote sensing: A case study in Zhoushan, China. (Masters Dissertation), Zhejiang University, Hangzhou.

Long, H., Liu, Y., Hou, X., Li, T., \& Li, Y. (2014). Effects of land use transitions due to rapid urbanization on ecosystem services: Implications for urban planning in the new developing area of China. Habitat International, 44, 536-544. https://doi.org/10.1016/j.habitatint.2014.10.011

Lu, L., Zhan, Y., Ye, Y., Chen, J., \& Mou, Y. (2010). Regional ecosystem health assessment based on land use pattern: A case of study of Zhoushan Island. Acta Ecologica Sinica, 30(1), 245-252.

Millennium Ecosystem Assessment (MEA). (2003). Ecosystems and human well-being: A framework for assessment. Washington, DC: Island Press.

Millennium Ecosystem Assessment (MEA). (2005). Ecosystems and human well-being: Synthesis. Washington, DC: Island Press. 
National Bureau of Statistics of China. (2013). China statistical yearbook 2013. Beijing: China Statistical Press.

Natural Capital Project. (2015). InVEST User Guide. Retrieved from http://data.naturalcapitalproject.org/nightly-build/invest-users-guide/html/

Nelson, E., Sander, H., Hawthorne, P., Conte, M., Ennaanay, D., Wolny, S., Manson, S., \& Polasky, S. (2010). Projecting global land-use change and its effect on ecosystem service provision and biodiversity with simple models. PloS one, 5(12), e14327. https://doi.org/10.1371/journal.pone.0014327

Oost, A., Hoekstra, P., Wiersma, A., Flemming, B., Lammerts, E., Pejrup, M., Hofstede, J., Van der Valk, B., Kiden, P., \& Bartholdy, J. (2012). Barrier island management: Lessons from the past and directions for the future. Ocean $\&$ Coastal Management, 68, 18-38. https://doi.org/10.1016/j.ocecoaman.2012.07.010

Parsons, M.L., Walsh, W.J., Settlemier, C.J., White, D.J., Ballauer, J.M., Ayotte, P.M., Osada, K.M., \& Carman, B. (2008). A multivariate assessment of the coral ecosystem health of two embayments on the lee of the island of Hawaii. Marine Pollution Bulletin, 56(6), 1138-1149. https://doi.org/10.1016/j.marpolbul.2008.03.004

Price Department of the National Development and Reform Commission. (2013). The assembly of the national agricultural cost-benefit data 2013. Beijing: China Statistical Press.

Samways, M.J. (2000). A conceptual model of ecosystem restoration triage based on experiences from three remote oceanic islands. Biodiversity and Conservation, 9(8), 1073-1083. https://doi.org/10.1023/A:1008974702634

Samways, M.J., Hitchins, P.M., Bourquin, O., \& Henwood, J. (2010). Restoration of a tropical island: Cousine Island, Seychelles. Biodiversity and Conservation, 19(2), 425-434. https://doi.org/10.1007/s10531-008-9524-z

Saunders, A. (1990). Mapara: Island management 'mainland' style: Ecological restoration of New Zealand islands. Conservation Sciences Publication, 2, 147-149.

SCEP (Study of Critical Environmental Problems) (1970). Man's impact on the global environment. Cambridge: MIT Press.

Shi, S., Yang, X., Huang, H., \& Li, G. (2012). Research on island ecological restoration trend. Marine Environmental Science, 31(1).

Sovacool, B.K. (2012). Perceptions of climate change risks and resilient island planning in the Maldives. Mitigation and Adaptation Strategies for Global Change, 17(7), 731-752. https://doi.org/10.1007/s11027-011-9341-7

Stern, N.H. (2007). The economics of climate change: The Stern review. Cambridge: Cambridge University Press. https://doi.org/10.1017/CBO9780511817434

Tallis, H., \& Polasky, S. (2009). Mapping and valuing ecosystem services as an approach for conservation and natural resource management. Annals of the New York Academy of Sciences, 1162(1), 265-283. https://doi.org/10.1111/j.1749-6632.2009.04152.x

TEEB Foundations. (2010). The economics of ecosystems and biodiversity: Ecological and economic foundations. London \& Washington: Earthscan.

TEEB Synthesis. (2010). Mainstreaming the economics of nature: A synthesis of the approach, conclusions and recommendations of TEEB. London \& Washington: Earthscan.

Tol, R.S. (2009). The economic effects of climate change. The Journal of Economic Perspectives, 23(2), 29-51. https://doi.org/10.1257/jep.23.2.29

Tol, R.S. (2005). The marginal damage costs of carbon dioxide emissions: An assessment of the uncertainties. Energy Policy, 33(16), 2064-2074. https://doi.org/10.1016/j.enpol.2004.04.002

Wang, D., Shi, A., Wang, X., Zhang, Z., \& Sounghook, H. (2014). Assessment of island land ecosystem services value and their spatial distribution. Nature Environment and Pollution Technology, 13(4), 743. 
Wang, W., Guo, H., Chuai, X., Dai, C., Lai, L., \& Zhang, M. (2014). The impact of land use change on the temporospatial variations of ecosystems services value in China and an optimized land use solution. Environmental Science \& Policy, 44, 62-72. https://doi.org/10.1016/j.envsci.2014.07.004

Wang, X., Chen, W., Zhang, L., Jin, D., \& Lu, C. (2010). Estimating the ecosystem service losses from proposed land reclamation projects: A case study in Xiamen. Ecological Economics, 69(12), 2549-2556. https://doi.org/10.1016/j.ecolecon.2010.07.031

Wu, K., Ye, X., Qi, Z., \& Zhang, H. (2013). Impacts of land use/land cover change and socioeconomic development on regional ecosystem services: The case of fast-growing Hangzhou metropolitan area, China. Cities, 31, 276-284. https://doi.org/10.1016/j.cities.2012.08.003

Xi, X., Li, M., Zhang, Z., Zhang, Y., Zhang, D., Zhang, J., Dou, L., \& Yang, Y. (2013). Research on soil organic carbon distribution and change trend in middle-east plain and its vicinity in China. Earth Science Frontiers, 20(1), 154-165.

Xie, G., Lu, C., Leng, Y., Zheng, D., \& Li, S. (2003). Ecological assets valuation of the Tibetan Plateau. Journal of Natural Resources, 18(2), 189-196.

Xie, G., Zhang, C., Zhang, L., Chen, W., \& Li, S. (2015). Improvement of the evaluation method for ecosystem services value based on per unit area. Journal of Natural Resources, 30, 1243-1254.

Xie, G., Zhen, L., Lu, C., Xiao, Y., \& Chen, C. (2008). Expert knowledge based valuation method of ecosystem services in China. Journal of Natural Resources, 23(5), 911-919.

Xu, F.L., Lam, K.C., Zhao, Z.Y., Zhan, W., Chen, Y.D., \& Tao, S. (2004). Marine coastal ecosystem health assessment: A case study of the Tolo Harbour, Hong Kong, China. Ecological Modelling, 173(4), 355-370. https://doi.org/10.1016/j.ecolmodel.2003.07.010

Xu, L., Xu, X., Luo, T., Zhu, G., \& Ma, Z. (2012). Services based on land use: A case study of Bohai Rim. Geographical Research, 10, 004.

Ye, L. (2012). The study of forest organic carbon spatial variation and impact factors in Zhejiang Province. (Masters Dissertation), Zhejiang A\&F University, Lin' an, China.

Zhang, F., Du, Q., Ge, H., Liu, A., Fu, W., \& Ji, B. (2012). Spatial distribution of forest carbon in Zhejiang Province with geostatistics based on CFI sample plots. Acta Ecologica Sinica, 32, 5275-5286. https://doi.org/10.5846/stxb201201100055

Zhang, J., Fu, W., Du, Q., Zhang, G., \& Jiang, P. (2013). Determinants of spatial distribution of forest litter carbon densities in Zhejiang Province. Journal of Zhejiang A\&F University, 30(6), 814-820.

Zhang, X., Pan, D., Chen, J., Zhan, Y., \& Mao, Z. (2013). Using long time series of Landsat data to monitor impervious surface dynamics: A case study in the Zhoushan Islands. Journal of Applied Remote Sensing, 7(1), 073515-073515. https://doi.org/10.1117/1.JRS.7.073515

Zhao, B., Kreuter, U., Li, B., Ma, Z., Chen, J., \& Nakagoshi, N. (2004). An ecosystem service value assessment of land-use change on Chongming Island, China. Land Use Policy, 21(2), 139-148. https://doi.org/10.1016/j.landusepol.2003.10.003

Zhao, S., Li, M., \& Wu, C. (2015). Emergy valuation of ecosystem services in the Zhoushan marine area. Acta Ecologica Sinica, 35(3), 63-67. https://doi.org/10.1016/j.ecolind.2012.12.009

Zhoushan Bureau of Statistics. (2013). Zhoushan statistical yearbook 2013. Beijing: China Statistical Press.

Zhu, Y., Guan, D., \& Hu, Y. (2013). Dynamic of vegetation carbon storage and carbon density of farmland ecosystem in Pearl River Delta. Journal of Southern Agriculture, 44(8), 1313-1317. 
